
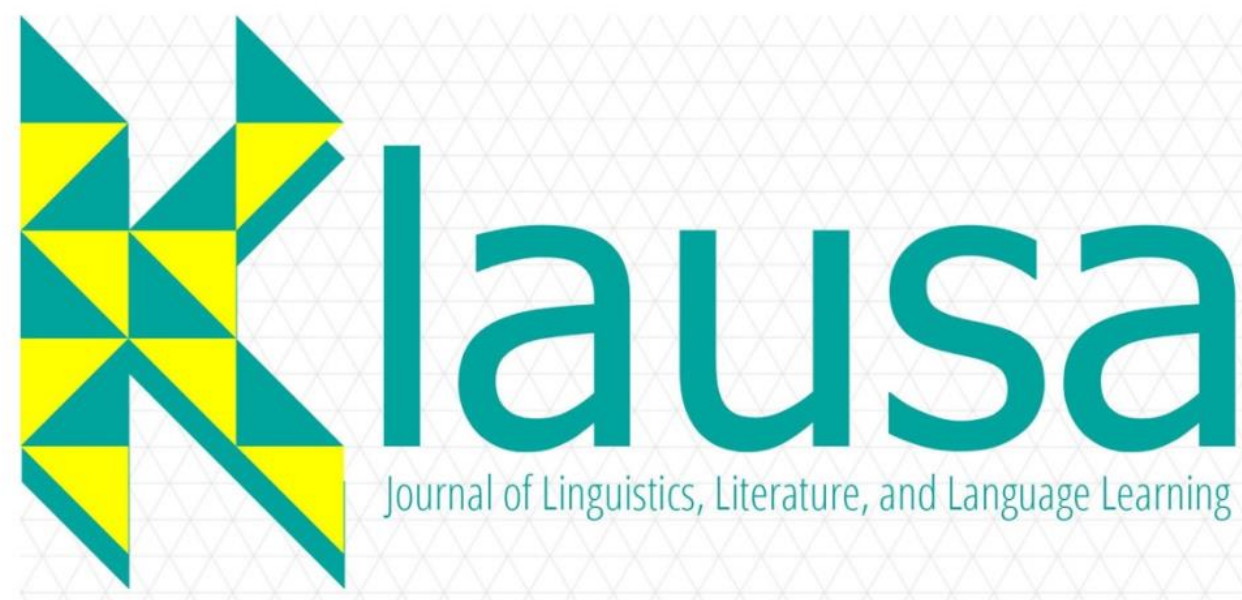

ISSN 2620-9527

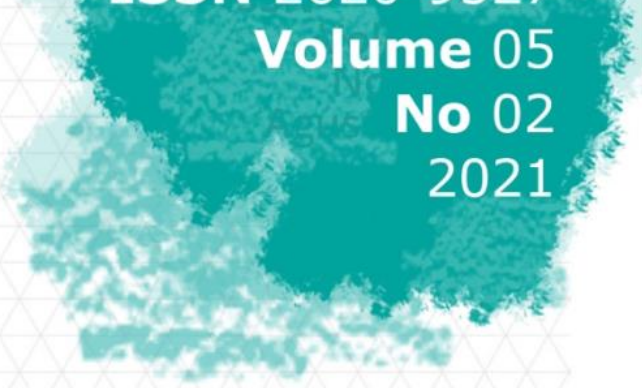

Journal of Linguistics, Literature, and Language Learning

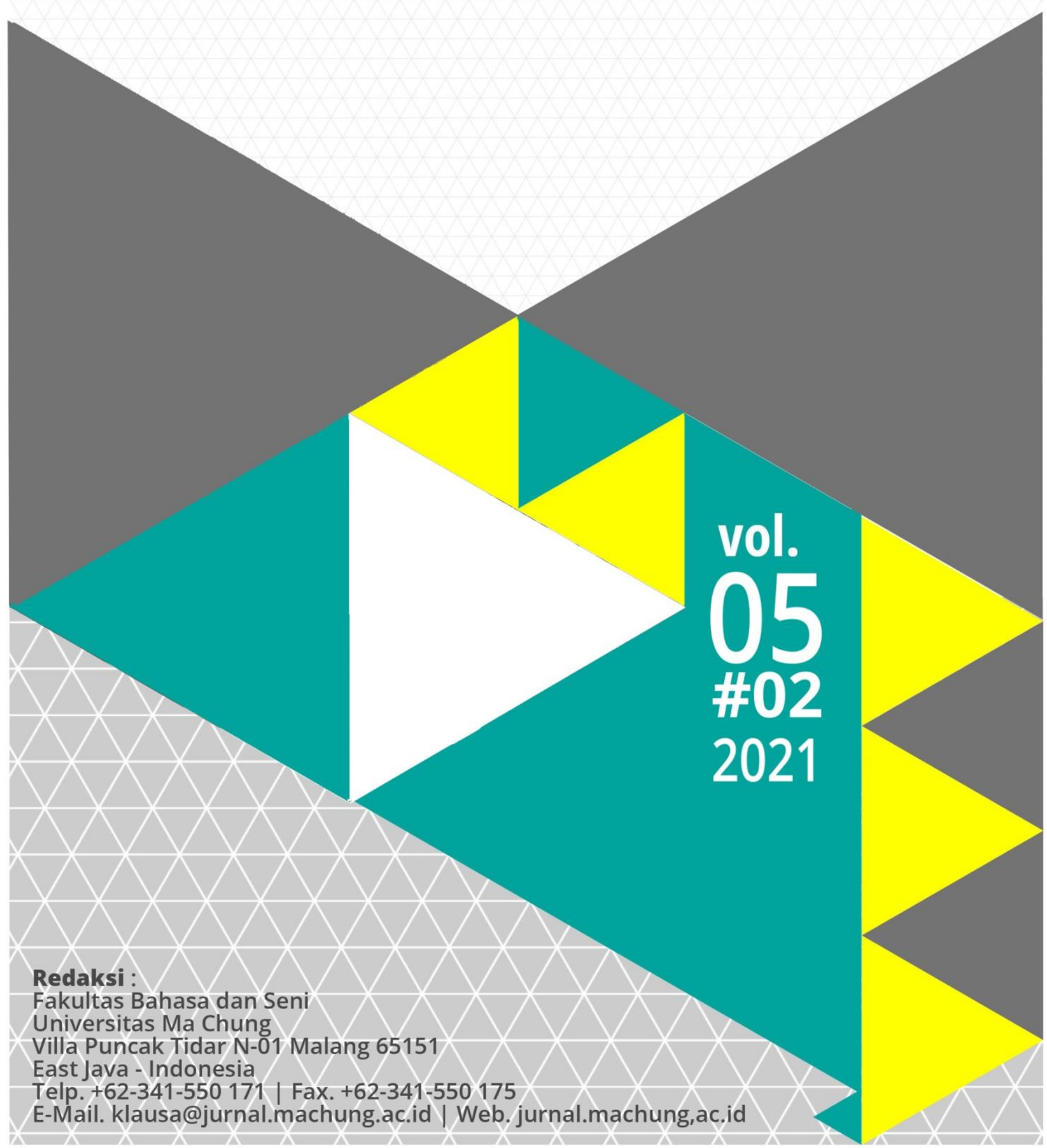


ISSN: $2301-4822(p)$

2620-9527 (e)

DOI:

\section{Kajian Linguistik, Pembelajaran}

Bahasa, dan Sastra

\section{Editorial Team}

Editor-in-Chief:Dr. Daniel Ginting

Journal Manager:Wawan Eko Yulianto, Ph.D.

Editors: Prof. Dr. Patrisius I. Djiwandono

Lilis Lestari Wilujeng, M.Hum.

Reviewers:F.X Dono Sunardi, M.A.

Dhatu Sitaresmi, MTCSOL.

Anggrah Diah Arlinda, MTCSOL.

Yohanna Nirmalasari, S.Pd., M.Pd.

Prof. A. Effendi Kadarisman, Ph.D.

Sisilia Halim, Ph.D.

Dr. Mundi Rahayu

Dr. Ross Wood

Dr. Leticia Araceli Salas Serrano

Publisher: Faculty of Language and Arts

Universitsas Ma Chung

Address: The Faculty of Language and Arts

$$
\begin{aligned}
& \text { Ma Chung University } \\
& \text { Villa Puncak Tidar N-01 (65151) } \\
& \text { Malang, East Java, Indonesia } \\
& \text { Email: jurnal.klausa@machung.ac.id }
\end{aligned}
$$

Frequency: Twice a year 


\section{CONTENTS}

FOREWORD

iii

SOLIDARITY IN THE TOURING NARRATIVE OF S.U.U.A.L (SCOOTER UIN ULUL ALBAB)

MALANG VESPA COMMUNITY: A CRITICAL DISCOURSE ANALYSIS APPROACH

Yunia Dewi Fathmawati ${ }^{1}$

THE ROLE OF PARENTAL GUIDANCE ON VOCABULARY ACHIEVEMENT IN AN INDONESIAN EFL ELEMENTARY EDUCATION SETTING

Christian Edison Bani ${ }^{1}$, Sahiruddin ${ }^{2}$, Ika Nurhayani ${ }^{3}$

MENELAAH POTENSI SASTRA PARIWISATA DI TELAGA SARANGAN

Ardi Wina Saputra ${ }^{1}$, Rustiati ${ }^{2}$

MAKNA KULTURAL DALAM LEKSIKON PERHIASAN PENGANTIN SUNDA PRIANGAN (KAJIAN ETNOLINGUISTIK)

Elda Mnemonica Rosadi ${ }^{1}$, Retty Isnendes ${ }^{2}$, Mahmud Fasya ${ }^{3}$

133

THE ENVIRONMENTAL ASPECTS OF ALEXANDRE DUMAS'

THE COUNT OF MONTE CRISTO

Gusti Ayu Made Suarniti ${ }^{1}$ 


\title{
THE ENVIRONMENTAL ASPECTS OF ALEXANDRE DUMAS' THE COUNT OF MONTE CRISTO
}

\author{
Gusti Ayu Made Suarniti ${ }^{1}$ \\ ${ }^{1}$ Universitas Warmadewa, Denpasar, Indonesia, raisuarniti78@gmail.com
}

\begin{abstract}
This research focused on "Setting of Alexandre Dumas' The Count of Monte Cristo". This research aims to find and analyze the kinds and the functions of setting that are found in Dumas' The Count of Monte Cristo. The theory for the kind of setting taken from Writing Essays About Literature by Griffith (2001) and the theory of function of setting taken from Concise Companion to Literature by Pickering and Hoeper (1981). The result of the research showed that four kinds of setting and five functions of setting were found in Alexandre Dumas's The Count of Monte Cristo. The four kinds of setting found were setting of place, setting of time, setting of social environment, and setting of atmosphere. The five functions of setting found were setting as background for action, setting as antagonist, setting as a means of creating appropriate atmosphere, setting as a means of revealing character, and setting as means of reinforcing theme.
\end{abstract}

Keywords: Setting, kinds and function

\section{INTRODUCTION}

Setting, a part of literary works which commonly speaks of time and place of an action. Setting can be found in many, if not all, works of literature. Literature itself is a form of works which can be written or spoken artistically in which a person is able to convey their ideas, visions, and creativity. Literature can be defined as creative imaginative works of art whether written or spoken in the form of prose, poetry, drama, and film. A piece of literature may also be written by the author not only to express ideas and creativity, but also to mark their name in history. Kenney (1996) states that "underlying literary production is certainly the human wish to leave behind a trace of oneself through creative expression, which will exist detached from the individual and, therefore, outlast its creator". Writing it also serves the purpose of giving information or education to the reader, regardless of time. 
In the subject of literature, works of literature are often called literary works. Literary works mainly classified into three types; they are prose, poetry, and drama. Setting can be found in all three types. As the title implies, this research will try to analyze the setting found in a novel. Novel is a literary works in classified into the prose type. Novel (or prose in general) can be further divided into fiction and nonfiction. Nonfiction is a literary work which presents the very truth of an information, whether it is an event or regarding individual. It may take many forms, such as biography and autobiography. While nonfiction is based on truth and fact, fiction may not be so. Fiction according to Abrams (1999) "is any literal narrative, whether in prose or verse, which invented instead of being an account of events that in fact happened". In other words, prose is a literary works that is not based on fact, but instead based on the writer's creativity and imagination. The word prose is sometimes used simply as a synonym to the word "novel", due to it being associated to narrative works that are written in prose, which is novel, novella and short story. This association is true, considering prose itself can be divided into three types based on its length and word count.

Out of the three, novel is the kind of works of prose which has the largest number of content judging from its word count, which is around forty-five thousand words or more, compared to novella and short story which consist of one thousand to fifteen thousand words and fifteen thousand to forty-five thousand words respectively. Novel can be defined as a narrative that tells a complex and long story of a character's experiences through chain of events based on their causal relationship. An author may use novels to show their ideas, imaginations, and experiences to the reader from the perspective of the characters of the novel. A good novel is able to take the reader into the author's world by making them so engrossed to the story that they feel they are inside and participating in the events of the novel. This is also true for any literary works.

Just like other things in the universe, there are elements that makes up the novel. They are intrinsic and extrinsic elements. Intrinsic elements are the element which develops the narrative from within, such as plot, character, point of view, style, theme, and setting, which is the topic of this research. On the contrary, extrinsic elements are the elements which affects the narrative from outside of the work itself, such as the biography of the author and the social background of when and where the narrative is written. Both elements are equally important as the understanding of both elements are required to thoroughly enjoy and understand the work.

Just as the intrinsic elements and extrinsic elements are connected to each other, the same also applies to the kind of both elements. The plot of the novel is, and will always be affecting the other intrinsic elements, such as the character and the setting. All of the elements are interconnected to each other. Without the connections, the novel will crumble and won't be a good work of art. In analyzing a work, some of the elements are comparatively easier to identify than the other. This is not absolute, as it will always depend on the focus of the novel. 
As the title of this research suggests, the focus in this research is the setting of the novel. According to Kenney, setting is "that elements of fiction which reveals to us the where and when of events". This means setting is the place and the time in which the story takes place in the novel. The importance of setting in a novel can be seen on how it affects the other elements and the novel as a whole. The presence of a good and believable setting is important as a pathway to the author's narrative world, thus assisting the reader to understand the narrative and the idea better. The more detailed and well thought the settings are, the better understanding the reader has on the story.

Regarding the selected novel, Dumas' The Count of Monte Cristo is a novel which is primarily concerned with the theme of justice, vengeance, and forgiveness. It was first released in 1844 and is still considered a classic in modern times. According to Luc Sante, a Belgium writer and critic, "The Count of Monte Cristo has become a fixture of Western civilization's literature, as inescapable and immediately identifiable as Mickey Mouse, Noah's flood, and the story of Little Red Riding Hood." The main character, Edmond Dantes, is the first mate of the ship Pharaon and he is in love with and going to marry Mercedes, whom he has known for a long time. On his wedding day, he was wrongly accused of treason by his envious fellow ship mate and his jealous rival in love. He ended up getting arrested and imprisoned without trial in the Chateau d'If, an island fortress located off the shore of Marseille. Later, thanks to the guidance and help of his fellow prisoner, Abbe Faria, he managed to escape the prison and gained an amount of fortune. After that event, he became the Count of Monte Cristo, and is on his way to bring forth both his vengeance and justice upon those who have wronged him.

As seen in the description above, there are myriads of places and situations that may be found in this novel and this will be the topic of the research. Based on this, it seems interesting to find and analyze the kinds and function of settings in Dumas' The Count of Monte Cristo.

\section{METHOD OF RESEARCH}

Method of research is the procedure to determine the data source, to collect the data, and the method of analyzing the data. Methods of research that will be used in this research can be categorized into three steps: determining the data source, collecting the data, and analyzing the data.

Data source is where the data is taken from. The novel that will be the data source for this research is Dumas' The Count of Monte Cristo. The reason for this is because the novel is interesting to research and it is considered a classic, not to boot.

The process of collecting the data will be conducted in a form of library research. First, the data source will be read thoroughly in order to understand the content. Second, the data which are related to the problem will be noted and/or underlined. Third, the collected data will be further classified according to the scope of discussion. 
The data which have been collected will be analyzed descriptively by utilizing the aforementioned theories. Finally, the analyzed data will be served according to the scope of discussion.

\section{SETTING OF ALEXANDRE DUMAS' THE COUNT OF MONTE CRISTO}

\section{Settings Found in Dumas' The Count of Monte Cristo}

Place

This section described and analyzed the settings that are placed in Dumas' The Count of Monte Cristo. The first place in the story could be seen this narration: "Immediately, and according to custom, the ramparts of Fort Saint-Jean were covered with spectators; it is always an event at Marseilles for a ship to come into port." (p. 3) As for the next place, it is the residence of Dantes's father. The route that young Dantes needed to take was described as: “... Dantes, who, after having traversed La Canebiere, took the Rue de Noailles, and entering a small house, on the left of the Allees de Meillan, rapidly ascended four flights of a dark staircase." (p. 9) The next place was the Island of Monte Cristo, which the reader was already familiar with for a part of its name was in the title of the story. The following were Dantes's knowledge on the island: "The abbe did not know the Island of Monte Cristo; but Dantes knew it, and had often passed it, situated twenty-five miles from Pianosa, between Corsica and the Island of Elba, and had once touched there." (p. 133)

Based on the information above, the Island of Monte Cristo was located between Corsica and the Island of Elba, twenty-five miles (or around forty kilometers) from Pianosa. In essence, The Island of Monte Cristo was a rock in a shape of cone which seemed to be thrusted up by volcanic activity from under the sea.

Time

This section analyzed and described the time in Alexandre Dumas' The Count of Monte Cristo. The first time is when it is narrated that "On the 24th of February 1815, the lookout at Notre-Dame de la Garde signalled the three-master, the Pharaon from Smyrna, Trieste, and Naples." (p. 3) This explicitly mentions that the time was the 24th of February 1815. The ship that Edmond worked on as a sailor, the Pharaon, arrived at Marseille on the aforementioned date. It was quite easy to notice the setting of time that was mentioned like this. The date itself, 24th of February 1815, was important for the story as March 1st was the date when Napoleon returned from the Island of Elba. Edmond Dantes was imprisoned because he was tasked to deliver a letter to the Bonapartist party in Paris. The date 24 was also a misprint for 28 , and Dumas subsequently informed the reader of the inconsistency. This is because chronology was never Dumas' strong point, as stated in the notes (p. 877). The setting of time was also visible within the range of hours, minutes, or even seconds, not only the days, months, and years. In case of the excerpt above, the setting of time was at night, proven by the presence of moonbeams. The next 
time setting was more straightforward and similar to the first sample in the way of how the story told the time:

"'No, captivity has subdued me - I have been here so long.' 'So long? - when were you arrested, then?' asked the inspector. 'The $28^{\text {th }}$ of February, 1815, at half past two in the afternoon.' 'Today is the $30^{\text {th }}$ of July, 1816 - why, it is but seventeen months.' 'Only seventeen months,' replied Dantes. 'Oh, you do not know what is seventeen months in prison! - seventeen ages rather"' (p. 86)

As seen above, the time at the moment in the story was the $30^{\text {th }}$ of July, 1816. Other than the current time, the story also told the exact time of Dantes's arrest and how much time has passed between events. In this case, it has been seventeen months since the day Dantes was arrested on $28^{\text {th }}$ of February, 1815, at half past two in the afternoon. The duration between events was considered a part of time. Moreover, the reader was given the difference on how time was perceived between the inspector and Dantes. The inspector said that seventeen months were not a long time, but it was different for Dantes. As a sailor, who freely sailed the vast sea and moved from place to place all the time, being locked up in a same, dark place, within a dungeon for seventeen months felt like he was there for seventeen ages, as he said. This showed the difference on how time was perceived between the inspector, who acts as an example of a free man, and Dantes, our wrongly accused sailor who was arrested right on his long-awaited marriage day.

\section{Social Setting}

This section described and analyzed the social setting of The Count of Monte Cristo by Alexandre Dumas. The first social setting was about the custom of the village of the Catalans, whose physical settings were already described in the place section. The following was one the description of the village:

"For three or four centuries they have remained upon this small promontory, on which they had settled like a flight of seabirds, without mixing with the Marseillaise population, intermarrying, and preserving their original customs and the costume of their mother-country as they have preserved their language. (p. 15)"

Based on the excerpt, there was a custom within the village of the Catalans that has been practiced for three to four centuries. That custom was intermarriage, which meant the Catalans marries fellow Catalans, and not mixing their blood with the blood of Marseille. They preserved their original customs and language for three hundred to four hundred years this way.

The next social setting was about a peculiar subject: coffee. It seemed that there was a certain manner in how one drinks their coffee. Take a look of the excerpt below: 
"The cups of coffee were all prepared, with the addition of sugar, which had been brought for Albert. Monte Cristo and Haydee took the beverage in the original Arabian manner, that is to say, without sugar. (p. 608)"

Albert and the count were invited by Haydee to her room. They enjoyed some coffee and tobacco while conversing. The count and Haydee chose to drink in Arabian manner. Arabian manners involved drinking coffee without the addition of sugar. Albert took a different path than the two and added sugar to his coffee. Albert was a Parisian, and it could be assumed that this was the Parisian manner in drinking coffee. Although it was called manners, it felt more like a personal preference of something. In conclusion, there are two different manners on how one drinks his coffee: the Arabian manner and Parisian manner.

Atmosphere

From a social setting, let us move to the atmosphere. In order to know the atmosphere, knowledge of the context within the story was needed. The first atmosphere was around the third attack and death of Abbe Faria. One night, Edmond was awoken from the rest in his cell by a call that came from Abbe Faria's cell. Edmond rushed there and found the abbe with the symptoms which preceded the attacks. Seeing this, Edmond cried and shouted for help from the guards, as seen below:

'"Alas, my dear friend,' said Faria in a resigned tone, 'you understand, do you not, and I need not attempt to explain it to you?' Edmond uttered a cry of agony, and, quite out of his senses, rushed towards the door, exclaiming, 'Help, help!' (p. 135)"

The feelings of rush and urgency could be felt from Dantes's actions, and it was quite normal for him to react as such because of the circumstances. Abbe Faria was Dantes's beaming beacon of light that shone upon the darkness of the dungeon where Dantes was. Not only a symbol of hope, that abbe also was a teacher and he treated Faria like his own father. Seeing someone so close to you on a brink of death was quite a traumatic experience.

Continuing the analysis, the next atmosphere was when the Count of Monte Cristo visited his old home in Rue de Noailles, on the left side of Allees de Meillan. This was the first time in fourteen years since his arrest that he visited the dwellings that his father used to live in. Every step he took on the road leading to Allees de Meillan, he was struck with emotion which kept building up within his chest: "Each step he trod oppressed his heart with fresh emotion; his first and most indelible recollections were there; not a tree, not a street, that he passed but seemed filled with dear and cherished memories. (p. 171)" 
Edmond's heart was filled with nostalgia of the memories that he made there. Every tree that he passed, every bit of street that he traveled through, was filled with memories for Edmond. The closer he got to his destination, the stronger the feelings hit him.

\section{Functions of the Setting in Dumas' The Count of Monte Cristo}

Setting as Background for Action

The setting can be used as the background of a story; this was true for each one of them. The following were the analysis of setting as a background of action. The first one was about the place of the story, Chateau d'If. Chateau d'If, which place has been analyzed, serves the purpose of being the background for action. Edmond Dantes was falsely accused of treason and was imprisoned here. From the moment Edmond set foot here, the fortress prison of Chateau d'If became the background for action. Below was one of the moments where Chateau d'If was the background for action: "His guards, taking him by the arms and coat-collar, forced him to rise, and dragged him towards the steps that led to the gate of the fortress, while the police officer carrying a musket with fixed bayonet followed behind. (p.56)"

The above excerpt was the moment of Dantes's first landing on the Chateau d'If. The setting that became the background of the aforementioned excerpt was -and to be specific - the gate of Chateau d'If. As the background of the story, the Chateau d'If was important for the plot. If Edmond was imprisoned in any other prison and not the Chateau d'If, he would never meet Abbe Faria, find the treasure of Cardinal Spada, and ultimately become the Count of Monte Cristo. This meant the Chateau d'If was not a decorative background which could be swapped with any other prison, as it consisted of aspects that were important to the story.

\section{Setting as Antagonist}

The second function was as the antagonist of the story. Essentially, the antagonist was the one which interrupts the protagonist from achieving their goals. The first setting that was quite apparent of being an obstacle for Edmond to achieve his goal was the fortress prison: Chateau d'If. Dantes was wrongly accused of treason and was imprisoned here. After becoming a prisoner, his goal was to escape and be a free man. Alongside Abbe Faria, his newfound friend, Edmond tried to overcome the one that kept him from freedom: The Chateau d'If. As if it was alive, it brought misfortunes to Edmond's escape plan, one of them was the rebuilding of the seaside gallery, which raised the possibility of the two prisoner's attempt of escape being detected:

"the gallery on the sea side, which had long been in ruins, was rebuilt. They had repaired it completely, and stooped up with vast masses of stone the hole 
Dantes had partly filled in. ... Thus a new, a stronger, and more inexorable barrier was interposed to cut off the realization of their hopes." (p. 133)

As seen above, the unforeseen nature of the prison foiled their plan of escape. Their plan was to dig out a hole to the seaside gallery, which previously was in ruins, and make their way out from there to the sea. But alas, both Edmond and Faria could not proceed with the initial plan as the tunnel which they had dug was filled and blocked by stones from the reconstruction of the gallery. To conclude, the Chateau d'If served the function as an antagonist because it was the only thing in Edmond's way of escaping and achieving freedom. If Edmond could not 'defeat the antagonist'; that is, escape from Chateau d'If, he would not be able to retrieve the treasure of Cardinal Spada, become the Count of Monte Cristo, and ultimately execute his plot of revenge upon his adversaries.

Setting as a Means of Creating Appropriate Atmosphere

The third function was to create the appropriate atmosphere. What it meant by 'creating appropriate atmosphere' was the place, time, social setting, or the atmosphere was used to set the readers with an appropriate state of mind and arouses their expectation of future events. Take a look of the excerpt below:

"Monte Cristo noticed ... that Bertuccio signed himself in the Corsican manner; that is, had formed the sign of the cross in the air with his thumb, and as he seated himself in the carriage, muttered a short prayer. ... the steward's had continued to augment as they entered the village. Bertuccio, crouched in the corner of the carriage, began to examine with feverish anxiety every house they passed." (p. 344)

The above was the atmosphere, as it showed Bertuccio's response to the fact that he and the count were going to a house at Auteuil which the count had bought. The above responses, such as signing a cross in the air, muttering prayers, and crouching in the corner while examining every detail of the surrounding, were quite similar to that of anxiety and fear. It was clear to see that there was something in said house that made Bertuccio respond like such. This fact arouses the reader as to what exactly made Bertuccio like that. It was later revealed that Bertuccio murdered a man in that house in the past. Not only that, he also witnessed that man burying an infant under the garden of the house. In conclusion, the atmosphere of fear and anxiety alongside the foreshadowing in the house description functioned as a means to create an appropriate atmosphere.

\section{Setting as Means of Revealing Character}

On to the fourth function, setting could be used to reveal or introduce a certain trait of characters by observing how they react to a setting. The setting which had such function was Monte Cristo's house at Auteuil. As analyzed before, the house at Auteuil also served the function of creating an appropriate atmosphere. Based on Bertuccio's 
story, an infanticide and a murder took place there. Later, it was revealed that those two weren't the only crimes committed in the building. Monte Cristo speculated that Monsieur de Villefort and Baroness Danglars committed adultery in one of the rooms many years ago. On the night of Bertuccio's attempt of murder, the baby between M. de Villefort and Baroness Danglars was born, and Villefort decided to bury the baby under the garden of the house to hide the evidence the affair. The following was some of M. de Villefort's and Baroness Danglars's responses when the affair and the murder were mentioned by the count in a form of 'scary stories':

"'There was, above all, one room,' continued Monte Cristo, 'very plain in appearance, hung with red damask, which, I know not why, appeared to me quite dramatic.' ... Villefort and Madame Danglars remained for a moment, as if rooted to their seats; they questioned each other with vague and stupid glances." (p. 508)

\section{Setting as Means of Reinforcing Theme}

The fifth function was that it could be used to reinforce the theme of a story. This made it important to discuss the theme that was reinforced by the setting. One of the themes of The Count of Monte Cristo was changes in state and identity. There were a lot of instances where characters were transformed into a different state or even a different person. Edmond Dantes, the main character, was transformed into different states and identities throughout the story. He started as a respectable sailor and a loving son, fiancé, and friend. Then, he was an alleged Bonapartist and prisoner; he lost everything he owned; his father, his lover, and his position in society. In the prison, he was called Edmond Dantes no more; his new name was "Number 34". After his escape from Chateau $d^{\prime} I f$, he joined the smuggler crew which helped him out in the sea. After that, he dug out the treasure of Cardinal Spada, obtained riches beyond his imagination, and took the title of "Count of Monte Cristo". Sometimes, he even disguised himself under the persona of Abbe Busoni, Lord Wilmore, and Sinbad the Sailor. Not only him, other characters also happened to be transformed as well. Mercedes became a rich Parisian by the name of Countess of Morcerf; Fernand Mondego took the title of Count of Morcerf; Danglars, who was a ship's supercargo, became a Baron. As stated before, disguises were occasionally utilized in the story. In one instance, the Count of Monte Cristo disguised Valentine de Villefort so that she looks and feels like she was dead to avoid her being murdered by poison by her stepmother. Based on these facts, the story constantly provides the reader with changes of identity and state and reminds the reader that sudden changes can turn one's life upside down. This was why one of the themes of the story was 'changes of state and identity'.

The theme was reinforced by the place, which was the sea. Multiple times the sea made an appearance in the story; one of them was right after Edmond escaped from Chateau d'If. To escape the prison, Edmond hid inside the bag which serves as the coffin 
of Abbe Faria. Ultimately, the guards tossed him into the sea with a cannon ball tied to his feet: "Dantes had been flung into the sea, and was dragged into its depths by a thirtysix pound shot tied to his feet. The sea is the cemetery of the Chateau d'If." (p.143)

The sea is the setting which serves the purpose of reinforcing the theme. The act of Edmond being tossed into the sea symbolized the baptism ceremony in Christianity. Baptism is a religious rite where someone's forehead is sprinkled with or immersed in water. This rite symbolizes purification. In many denominations, the ceremony is performed on young children and is accompanied by name-giving. Being tossed into the sea, Edmond is baptized, his old life is purified, and new life begins as he left the name Edmond Dantes and took the title of The Count of Monte Cristo. In conclusion, the sea reinforced the theme of 'changes in identity and state' by symbolizing the water that is used in baptism rites.

\section{CONCLUSION}

Conclusion was the answer to the question in the analysis. This section provided the result of the research. The goal of this research, based on the scope of discussion, was to find out the kinds and functions of setting were found in Dumas' The Count of Monte Cristo. According to the analysis of the data, it was proven that there were four kinds of setting: setting of place, setting of time, setting of social environment, and setting of atmosphere. Settings of place and time were abundant and quite easy to notice, while settings of social environment and atmosphere could be found by observing the interactions of the different elements of the story. Not only that, but some of the settings also even had a function of their own.

The second conclusion of the research was the fact that there were five function of setting which were found in The Count of Monte Cristo, they were setting as the background for action, setting as antagonist, setting as a means of creating atmosphere, setting as a means of revealing character, and setting as means of reinforcing theme.

\section{BIBLIOGRAPHY}

Abrams, M. H. 1999. A Glossary of Literary Terms. Heinle \& Heinle.

Baldick, C. 2001. The Concise Oxford Dictionary of Literary Terms.Oxford.

Childs, P. and Fowler, R. 2006. The Routledge Dictionary of Literary Terms. Routledge.

Cuddon, J. A. 2013. A Dictionary of Literary Terms and Literary Theory. Wiley-Blackwell.

Dumas, A. 1997. The Count of Monte Cristo. Wordsworth Editions Limited.

Dumas, A. 2004. The Count of Monte Cristo. Barnes \& Noble Books.

Forster, E. M. 2002. Aspects of the Novel. RosettaBooks LLC.

Freytag, G. 1900. Freytag's Technique of the Drama. Scott, Foresman and Companny.

Griffith, K. 2001. Writing Essays About Literature. Heinle.

Kenney, W. 1966. How to Analyze Fiction. Monarch Press. 
Klarer, M. 2004. Introduction to Literary Studies. Routledge.

Pickering, J. H. and Hoeper, J. D. 1981. Concise Companion to Literature.

Macmillan Publishing Co., Inc.

Wellek, R. and Warren, A. 1949. Theory of Literature. Harcourt, Brace and Company, Inc 